\title{
Nilai moral Pancasila untuk membangun bangsa di era globalisasi
}

\section{Anisa Nur Padilah ${ }^{1}$, Dinie Anggraeni Dewi ${ }^{2}$}

Prodi PGSD, Universitas Pendidikan Indonesia Kampus Daerah Cibiru, Bandung, Indonesia

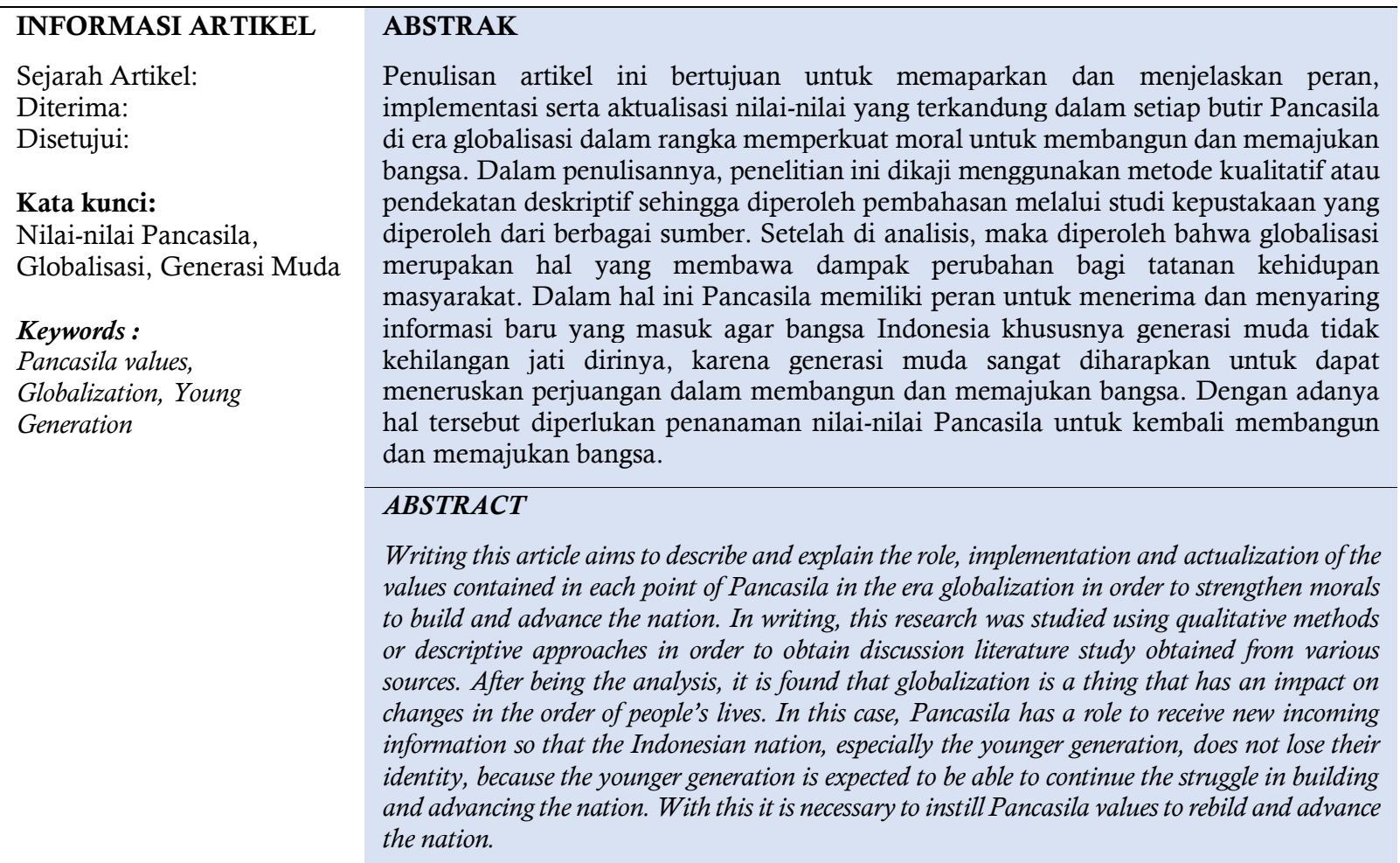

\section{Pendahuluan}

Pancasila diartikan sebagai serangkaian nilai, yakni nilai ketuhanan, nilai kemanusiaan, nilai persatuan, nilai kerakyatan, serta nilai keadilan. Nilai Pancasila tersebut merupakan nilai kesatuan yang utuh dan bulat dalam rangka mencapai cita- cita yang sama (Puji, 2016) Pancasila yang merupakan serangkaian nilai tidak hanya diciptakan ataupun dihasilkan dari perenungan serta pemikiran seseorang, melainkan digali dari nilai kebudayaan serta kekayaan masyarakat Indonesia itu sendiri.

Globalisasi merupakan salah satu hal yang membawa dampak perubahan langsung bagi tatanan kehidupan masyarakat. Belakangan ini, banyak generasi muda yang mengalami kerusakan moral akibat banyak faktor yang mempengaruhi dirinya diantaranya karena adanya dampak dari arus globalisasi yang berlangsung secara terus menerus, lingkungan tempat tinggal dan bergaul, media elektronik yang semakin canggih, serta hal-hal negatif lain yang dapat memberikan pengaruh bagi kehidupannya. Keadaan tersebut menunjukkan bahwa nilai-nilai Pancasila sudah mulai luntur di kehidupan masyarakat. Keadaan ini juga cukup memprihatinkan karena generasi muda merupakan generasi yang diharapkan dapat meneruskan perjuangan-perjuangan dalam rangka membangun bangsa Indonesia. Hal ini dikarenakan Negara Indonesia tidak akan maju apabila dibangun oleh generasi yang tidak bermoral. Sehingga diperlukan adanya pembelajaran dalam rangka penguatan moral bagi generasi muda. Dengan adanya hal tersebut, di era globalisasi ini Pancasila sangat 
diperlukan dalam upaya membatasi diri untuk memilih budaya mana yang dapat dipilih serta dapat bermanfaat bagi kehidupan bangsa Indonesia.

Selain itu, diperlukan juga adanya kesadaran untuk menyikapi globalisasi ini secara bijak agar globalisasi dapat memberikan pengaruh dan manfaat bagi perkembangan serta kemajuan bangsa Indonesia itu sendiri. Di era globalisasi ini juga mengharuskan kita agar dapat mengupayakan kembali implementasi serta aktualisasi nilai- nilai Pancasila. Hal ini perlu diupayakan agar generasi penerus bangsa senantiasa menghayati serta mengamalkan nilai luhur yang termuat dalam Pancasila, serta nilai-nilai luhur tersebut dapat tetap digunakan sebagai acuan hidup bangsa Indonesia di era globalisasi ini. Hal ini dikarenakan Pancasila merupakan pedoman hidup bagi bangsa Indonesia dalam melaksanakan kehidupan bermasyarakat, berbangsa dan bernegara. Sehingga, para generasi muda harus memahami fungsi Pancasila dan mengimplementasikan serta mengaktualisasikannya dalam kehidupan sehari-hari (Elisken, 2019).

\section{Metode}

Metode jenis penelitian ini merupakan metode kualitatif atau pendekatan deskriptif. Penelitian ini mengkaji bagaimana peran Pancasila di era globalisasi dalam memperkuat moral untuk membangun dan memajukan bangsa. Penelitian ini bersifat kualitatif dan menggambarkan peran Pancasila.

Peneliti bertindak sebagai human instrumen atau instrumen dalam penelitian ini. Karena dalam pengambilan kesimpulan peneliti akan membuat fokus penelitian, mencari teori dari berbagai sumber kepustakaan seperti buku, jurnal, artikel, skripsi atau media lain yang mendukung dalam pembuatan artikel mengenai peran pancasila di era globalisasi. Kemudian, dari data yang didapat, dilakukan sebuah analisis dan penarikan kesimpulan.

\section{Hasil dan Pembahasan}

Implementasi dan aktualisasi nilai yang terkandung di dalam Pancasila sangat diharapkan bagi kehidupan. Hal ini dikarenakan nilai- nilai yang terkandung di dalam Pancasila dapat memberikan pengaruh yang cukup besar bagi bangsa Indonesia untuk membentuk pola cara berpikir, cara bersikap, cara bertindak sekaligus dapat memberikan arahan bagi kehidupan. Notonagoro (Sunoto, 1991: 50) mengemukakan bahwa Pancasila merupakan pandangan hidup yang dijadikan sebagai alat untuk mempersatukan bangsa. Hal ini dikarenakan nilai yang terkandung di dalam Pancasila merupakan ideologi yang digunakan sebagai acuan bagi kehidupan

Di arus globalisasi ini nilai- nilai Pancasila harus terus dipertahankan agar generasi penerus senantiasa dapat mengamalkan nilai- nilai yang termuat di dalam Pancasila sehingga nilai-nilai yang termuat dapat tetap terjaga dan tetap menjadi pedoman bagi kehidupan bangsa Indonesia. Globalisasi merupakan suatu hal yang membawa perubahan langsung terhadap tatanan kehidupan masyarakat. Banyak generasi muda yang mengalami kerusakan/ dekadensi moral akibat berbagai hal yang mempengaruhinya mulai dari dampak buruk globalisasi, lingkungan tempat tinggal dan bergaul, media elektronik yang semakin canggih serta hal-hal negatif lain yang dapat memberikan pengaruh bagi kehidupannya (Putu, 2020).

Nilai-nilai Pancasila bersumber dari kepribadian bangsa sehingga nilai-nilai Pancasila dijadikan sebagai pandangan hidup bagi bangsa Indonesia karena nilai-nilai yang terkandung di dalamnya sesuai dengan keadaan dari bangsa Indonesia. Nilai tersebut diantaranya nilai kebenaran, nilai kebaikan, nilai keadilan serta nilai kebijaksanaan bagi kehidupan.

Sampai saat ini terlihat kondisi masyarakat sangat memprihatinkan terutama pada aspek moral/karakter. Hal ini marak terjadi bahkan menimpa kepada para generasi muda yang dianggap 
sebagai generasi penerus yang harus meneruskan perjuangan- perjuangan dalam rangka membangun dan memajukan bangsa. Dengan adanya hal tersebut, dunia pendidikan yang dianggap memiliki fungsi paling penting dalam melahirkan generasi yang tidak hanya cerdas dalam berpikir mendapat sorotan serta perhatian yang cukup tajam karena dunia pendidikan dianggap kurang serius dalam rangka memberikan pengarahan sekaligus mendidik generasi muda. Hal tersebut dapat dilihat dari banyaknya masalah yang menyangkut kasus-kasus pada pelajar seperti tawuran, kasus kriminal, bullying dan kasus-kasus lainnya.

Dengan adanya kerusakan/dekadensi moral tersebut Pemerintah merealisasikan program "Pendidikan Budaya dan Karakter Bangsa". Langkah tersebut dianggap sebagai langkah yang paling tepat untuk menghadapi masalah yang berkaitan dengan moral ini. Hal ini dikarenakan Negara tidak akan pernah maju apabila dibangun oleh generasi tidak bermoral, sehingga diperlukan adanya pembelajaran dalam rangka penguatan moral bagi generasi muda. Selain pembelajaran, sikap mentalitas kuat yang berlandaskan Pancasila juga sangat diperlukan dalam kehidupan karena kemajuan serta keberhasilan bangsa merupakan faktor penentu di era perubahan ini (Mona, 2020)

\section{Nilai-Nilai Pancasila}

Pancasila merupakan pedoman dan pandangan hidup yang tumbuh dan berakar dalam kepribadian bangsa Indonesia sehingga Pancasila ini dijadikan sebagai hal yang mengatur hidup ketatanegaraan (Septianingsih, 2018). Adapun Nilai-nilai yang termuat dalam setiap sila Pancasila adalah sebagai berikut.

1. Sila Pertama, merupakan perwujudan manusia sebagai makhluk Tuhan Yang Maha Esa dalam melakukan segala sesuatu harus dijiwai dengan nilai-nilai keagamaan/ religius.

2. Sila Kedua, merupakan perwujudan sikap yang sesuai dengan norma dan aturan serta negara harus memperhatikan dan menjunjung tinggi setiap warga negara sebagai makhluk yang beradab.

3. Sila ketiga, merupakan perwujudan nilai untuk mengakui, menghargai sertamenjunjung tinggi keberagaman serta perbedaan yang ada mulai dari agama, ras, golongan, suku. Hal tersebut dimaksudkan untuk memperkuat persatuan dan kesatuan yang juga tertuang dalam semboyan.

4. Sila Keempat, merupakan perwujudan nilai demokrasi. Dalam pelaksanaannya, demokrasi harus mementingkan dan mengutamakan hak-hak rakyat. Selain itu, sila keempat juga mengandung makna bahwa musyawarah dan mufakat sangat penting untuk dilakukan (Fara, 2020).

5. Sila Kelima, merupakan perwujudan nilai keadilan yang terjadi dalam kehidupan. Dengan nilai-nilai Pancasila tersebut dapat terbentuk karakter bangsa (Putu, 2017), yaitu takwa dan percaya terhadap tuhan yang maha esa, mengakui adanya persamaan tanpa membedabedakan, menjadikan persatuan dan kesatuan sebagai kepentingan bersama, mengambil setiap keputusan dengan musyawarah mufakat, dapat bersikap adil.

Sehingga dapat diambil kesimpulan bahwa Pancasila bukanlah pedoman yang bersifat praksis melainkan merupakan nilai etika yang dijadikan sebagai sumber norma (Heryansyah, 2014).

\section{Implementasi dan Aktualisasi Pancasila sebagai Keharusan Moral}

Lickona (2012: 57) membagi sikap moral menjadi beberapa komponen yakni pengetahuan moral, perasaan moral serta perbuatan moral. Ketiga unsur moral tersebut memiliki tujuan untuk membentuk individu yang memiliki pemikiran terhadap moral dalam kehidupan. Hal ini dikarenakan seseorang akan dikatakan memiliki karakter apabila perilakunya sudah memahami serta memiliki 
kaidah moral. Dalam rangka mengaktualisasi dan mengimplementasi nilai-nilai Pancasila memerlukan suatu keadaan yang bisa mendorong tercapainya aktualisasi dan implementasi nilai Pancasila.

\section{Tantangan Pancasila di Era Globalisasi}

Globalisasi diartikan sebagai suatu proses yang membawa dampak perubahan langsung bagi tatanan kehidupan masyarakat. Salah satunya adalah memudarnya rasa nasionalisme serta rusaknya moral generasi muda. Beberapa pengaruh yang muncul tidak akan langsung berpengaruh terhadap nasionalisme, akan tetapi secara global pengaruh globalisasi akan menjadikan nasionalisme bangsa dan negara berkurang bahkan hilang (Yudhanegara, 2015). Dengan adanya hal tesebut, Pancasila sebagai pedoman hidup bangsa harus bisa menjadi benteng yang kuat dalam rangka menghadapi tantangan arus globalisasi yang terus berlangsung.

Lunturnya jati diri serta pemahaman masyarakat terhadap Pancasila sudah mulai hilang akibat adanya kemajuan di era globalisasi ini. Sebagian dari masyarakat menganggap bahwa Pancasila hanya simbol negara dan masyarakat juga mulai melupakan nilai-nilai yang termuat dalam Pancasila.

Lunturnya nilai-nilai Pancasila dikatakan sebagai masalah besar yang akanberpengaruh kepada pembangunan bangsa. Fenomena ini sudah terlihat dengan adanya kemerosotan/ dekadensi moral serta perilaku dalam berperilaku dan bertindak yang terjadi pada generasi muda. Hal ini menunjukan bahwa pengaruh globalisasi membuat generasi muda kehilangan jati diri serta kepribadian sebagai bangsa Indonesia. Padahal, generasi muda merupakan generasi penerus yang akan menentukan bagaimana langkah kehidupan ke depan (Rusdiyani, 2016). Namun, para generasi muda beranggapan bahwa mempertahankan komitmen pendahulu dan para pendiri bangsa dalam memperjuangkan dan mempertahankan nilai-nilai luhur Pancasila bukanlah hal yang mudah (Anugrah, 2018). Akan tetapi, apabila hal tersebut terus dibiarkan maka moral generasi muda akan semakin rusak serta akan timbul tindakan- tindakan yang menyimpang jauh dari nilai-nilai Pancasila. Sehingga, Pancasila diharapkan bisa menyaring seluruh dampak yang akan ditimbulkan dari globalisasi agar tidak terjadi perubahan dalam tatanan kehidupan masyarakat. Sehingga, apabila Pancasila mampu menyaring segala dampak yang ditimbulkan maka masyarakat juga mampu mewujudkan segala cita-cita yang diharapkan oleh bangsa.

\section{Implementasi dan Aktualisasi Nilai Pancasila di Arus Globalisasi}

Globalisasi merupakan suatu proses perubahan yang tidak bisa dihindari dan dihilangkan oleh masyarakat di semua kalangan. Dengan adanya hal tersebut, diperlukan adanya pembelajaran serta pengembangan kembali nilai-nilai Pancasila khususnya bagi generasi muda. Implementasi dan aktualisasi nilai-nilai Pancasila di era globalisasi dalam rangka memperkuat moral bangsa dapat dilakukan dengan menumbuhkan kembali sikap dan rasa nasionalisme. Selain itu, dapat juga dilakukan melalui pendidikan Pancasila dalam rangka membangun karakter generasi muda. Hal ini dikarenakan pendidikan dianggap sebagai prioritas utama dalam rangka mencetak generasi muda yang memiliki karakter serta moral sehingga dapat meneruskan perjuangan dalam membangun dan memajukan bangsa, karena dalam rangka membangun serta memajukan bangsa tidak hanya dilakukan oleh orang-orang yang cerdas intelektual saja, akan tetapi cerdas juga dalam moral. Hal ini dikarenakan di era global ini banyak sekali budaya yang masuk dan kita tidak dapat menolak masuknya budaya-budaya yang masuk dari Negara lain itu (Irhandayaningsih, 2016). Sehingga, Dalam rangka mengimplementasi dan mengaktualisasi nilai-nilai Pancasila diperlukan adanya kesadaran agar hal tersebut dapat terlaksana dengan baik. Sehingga, dalam prosesnya diperlukan nilai-nilai dasar yang terdapat dalam butir Pancasila yang harus diamalkan (Yanto, 2016). Dengan 
adanya arus globalisasi yang terus maju dan berkembang nilai-nilai yang terkandung di dalam Pancasila senantiasa untuk terus diamalkan dan dipertahankan.

\section{Pentingnya Implementasi dan Aktualisasi Nilai-Nilai Pancasila di Era Globalisasi}

Pancasila diartikan sebagai sistem nilai yang diambil dari kebudayaan dan harta kekayaan masyarakat itu sendiri untuk dijadikan sebagai acuan bagi kehidupan bangsa Indonesia dalam rangka berperilaku dan bertindak. Pancasila juga merupakan dasar Negara yang dijadikan acuan dalam menghadapi segala ancaman dan tantangan globalisasi yang terus maju dan berkembang ini. Dengan adanya hal tersebut, Pancasila memiliki peranan dalam rangka menyaring dan memilih nilai-nilai baru yang masuk agar senantiasa diselaraskan dengan nilai- nilai Pancasila itu sendiri (Siti, 2017). Sehingga, nilai-nilai baru tersebut dapat terus dijadikan sebagai nilai kepribadian bangsa Indonesia. Sehingga, untuk melestarikan nilai- nilai yang terkandung di dalam Pancasila diharapkan banyak terlahir generasi muda yang dapat meneruskan perjuangan dalam rangka membangun dan memajukan bangsa di era globalisasi ini.

\section{Simpulan}

Kemajuan yang terus berlangsung yang mengakibatkan adanya perubahan dalam tatanan kehidupan akibat adanya arus globalisasi menjadikan dampak- dampak negatif yang bermunculan tidak dapat dihindari dan dihilangkan oleh masyarakat. Hal tersebut tentu sangat memberikan pengaruh terhadap cara berperilaku dan bertindak dalam menjalani kehidupan. Dengan adanya hal tersebut Pancasila memiliki peranan paling penting untuk tetap mempertahankan dan melestarikan semua nilai yang termuat dalam Pancasila. Pancasila juga diharapkan dapat terus menyaring serta memilih segala informasi dan nilai baru yang masuk sehingga nilai-nilai tersebut dapat terus dijadikan sebagai nilai kepribadian bangsa. Pancasila juga harus terus dipertahankan agar sikap nasionalisme dari masyarakat tidak luntur. Agar nilai Pancasila dapat tetap bertahan maka diperlukan generasi muda yang cerdas dalam berpikir dan moral agar senantiasa dapat meneruskan perjuangan dalam rangka membangun dan memajukan bangsa. Karena, generasi yang cerdas adalah generasi yang bisa kuat dan teguh pada kepribadian jati dirinya, sehingga diperlukan persiapan untuk melahirkan generasi muda yang cerdas dalam berpikir dan moral karena masa depan bangsa ada di tangan generasi muda (Rianto, 2015).

\section{Referensi}

Puji, Ambiro. 2016. Implementasi nilai- nilai Pancasila bagi siswa di era globalisasi. Jurnal Pancasila dan Kewarganegaraan, 4(2), 440-450.

Putu, Luh Swandewi \& Luh De Liska. 2020. Implementasinilai-nilai Pancasila dalam penguatan karakter bangsa. Jurnal Widyadari, 21(2), 676-687.

Siti, Syifa A. 2017. Pancasila di arus globalisasi dalam memperkuat reformasi moral indonesia. [Online].

https://publikasiilmiah.ums.ac.id/bitstream/handle/11617/10775/7\%20Syifa\%20Siti\%20A ulia.pdf? sequence $=1 \&$ isAllowed $=\mathrm{y}$ (diakses pada tanggal 14 Maret2021).

Fara, Ayura D. 2020. Nilai-nilai Pancasila. [Online]. https://mahasiswa.yai.ac.id/v5/d atamhs/tugas/1913290009/11Makalah\%20pancasila\%20yura\%20f.pdf (diakses pada tanggal16 Maret 2021).

Irhandayaningsih, Ana. 2016. Peranan Pancasila dalam menumbuhkan kesadaran nasionalisme generasi muda di era global. [Online]. https://webcache.googleusercontent.com/search?q=cache:7Dcum 
OrD410J:https://ejournal.undip.ac.id/index.php/humanika/article/view/4595/4180+\&cd= $\underline{4 \& \mathrm{hl}=\mathrm{id}} \underline{\& \mathrm{ct}=\mathrm{clnk} \& \mathrm{gl}=\mathrm{id}}$ (diakses padatanggal 26 Maret 2021).

Yudhanegara, H Firman. 2015.Pancasila sebagai FilterPengaruh Globalisasi TerhadapNilai-Nilai Nasionalisme. JurnalCendekia Ilmu Administrasi Negara, 8(2), 165-179.

Elisken, Silviana. 2019. PerananPancasila dalammenumbuhkan kesadaran nasionalisme generasi muda di era global. [Online]. https://osf.io/7fjmt (diakses pada tanggal 27 Maret 2021).

Mona, Muhammad. 2020. Kekuatan nilai-nilai Pancasila dalammembangun kepribadianmasyarakat Indonesia. JurnalKebudayaan dan Keagamaan, 15(1), 121-138.

Rusdiyani, Efi. 2016. Pembentukan karakter dan moralitas bagi generasi muda yang berpedoman pada nilai-nilai Pancasila serta kearifan lokal. [Online]. https://publikasiilmiah.ums.ac.id/bitstream/handle/11617/10740/4\%20Efi\%20Rusdiyani.p df? sequence $=1 \&$ isAllowed $=y$ (diaksespada tanggal 27 Maret 2021).

Rianto, Hadi. 2015. Peran pendidikan Pancasiladan Kewarganegaraanmembangun generasi cerdas dan berkarakter. Jurnal Pendidikan Sosial, 2(1), 14-20.

Putu, I. 2017. Pancasila sebagai paradigma pembangunan bangsa Indonesia. [Online]. https://simdos.unud.ac.id/uploads/file pendidikan_1 dir/7ef5c8c c00c99ed72f0fbb49007b35f1.pdf (diakses pada tanggal 27 Maret2021).

Heryansyah, Despan. 2014. Tanggung Jawab Pemuda terhadap Masa Depan Pancasila. Jurnal Hukum IUS QUIA IUSTUM, 4(21), 607-631.

Yanto, Dwi. Pengamalan nilai-nilai Pancasila sebagai pandangan hidup dalam kehidupan sehariHari. Jurnal Kopertais Wilayah XI Kalimantan, (14)25, 35-45.

Septianingsih, Ayu. 2018. Pentingnya menerapkan ilai-nilai Pancasila di lingkungan masyarakat. [Online].https://webcache.googleusercont $\quad-\quad$ ent.com/search?q=cache:UPoA0 YbUUqwJ:https://osf.io/3dnmr/ download/\%3Fformat\%3Dpdf+ $\underline{\& c d=3 \& h l=i d \& c t=c l n k \& g l=i d}($ diakses pada 27 Maret 2021).

Anugrah, Wendi. 2018. Urgensi memahami dan mengimplementasikan nilai-nilai Pancasila dalam kehidupan sehari-hari sebagai sebuah bangsa. Jurnal Bhinneka Tunggal Ika, 5(2), 123-128. 